\title{
PERAN KPU DALAM MENINGKATKAN PARTISIPASI POLITIK MASYARAKAT DALAM PEMILIHAN UMUM PRESIDEN DAN WAKIL PRESIDEN 2014 DI KOTA MALANG
}

\author{
Muhammad Hidayansyah, Trisakti Handayani, M. Syahri \\ FKIP Universitas Muhammadiyah Malang, Indonesia \\ Email: dayatkonte2010@gmail.com
}

\begin{abstract}
ABSTRAK
Pemilihan umum presiden dan wakil presiden merupakan acara lima tahun sekali yang dilaksanakan di Indonesia, kegiatan ini sebagai wahana menyalurkan segala aspirasi masyarakat terutama dalam mempengaruhi keputusan politik, dan Penelitian ini bertujuan untuk mengetahui peran dan partisipasi masyarakat Kota Malang dalam pemilihan presiden dan wakil presiden tahun 2014 di Kota Malang, selain itu untuk mengetahui peran KPU Kota Malang dalam pemilihan umum presiden dan wakil presiden 2014, dan untuk menjelaskan faktor pendukung dan penghambat partisipasi masyarakat dalam pemilihan presiden dan wakil presiden 2014.Penelitian ini menggunakan Model penelitian deskriptif, yaitu suatu model penelitian dengan mencatat, mendeskripsikan dan menginterpratasikan peran KPU dalam meningkatkan partisipasi politik masyarakat dalam pemilihan umum prseiden dan wakil presiden 2014 di Kota Malang, dan penelitian ini menggunakan tiga teknik pengumpulan data yaitu wawancara, dokumentasi dan observasi. Berdasarkan hasil penelitian, diperoleh hasil bahwa peran KPU dalam meningkatkan partisipasi politik masyarakat dalam pemilihn umum presiden dan wakil presiden 2014 di Kota Malang sangat besar. Artinya ini sesuai dengan realita dan fakta yang terjadi di lapangan, bahwa tahun 2014 partisipasi masyarakat Kota Malang sangat meningkat. Hal ini didukung oleh hasil wawancara dan observasi kepada pememrintahan Kota Malang, Partai Politik dan Masyarakat Kota Malang, selain itu hal yang paling mendukung adalah hasil perthitungan suara di Kota Malang, menunjukan sebanyak 70\% masyarakat Kota Malang ikut berpartisipasi dalam pemilihan umum presiden dan wakil presiden 2014 di Kota Malang.
\end{abstract}

Kata Kunci : Peran KPU, Partisipasi Masyarakat.

\begin{abstract}
General election for president and vice president is an event held every five years in Indonesia. This is a program which is used for channeling the aspirations of all communities, especially in influencing political decisions. This study aims to determine the role and participation of Malang communities in the presidential and vice presidential elections 2014. Besides, this study also aims to determine the role of General Elections Commission (KPU) of Malang in general election of president and vice president in 2014, and to explain the enabling and inhibiting factors of communities' participation in the election of president and vice president in 2014. The approach used in this study is descriptive study, which is a study model by noting, describing and interpreting the role of KPU in increasing the communities' political participation in the elections of president and vice president 2014 in Malang. This study uses three methods in collecting the data. They are interview, documentation, and observation. Based on the result of the study, it can be concluded that the General Elections Commission has a big role in increasing communities' political participation in the elections of president and vice president 2014 in Malang. This means that it corresponds to the reality and the facts which occurred, that in 2014 the participation of Malang communities greatly increased. This is supported by the results of the interviews and observations to the government of Malang, Political Parties in Malang and also Malang communities. Besides, the most favorable case is the
\end{abstract}


result of vote counting in Malang which shows as much as $70 \%$ of people in Malang participated in the elections for president and vice president 2014 in Malang.

Key words: Role of the General Elections Commissions, Communities Participations

\section{PENDAHULUAN}

Demokrasi adalah bentuk atau mekanisme sistem pemerintahan suatu Negara sebagai upaya mewujudkan kedaulatan rakyat (kekuasaan warga Negara) atas Negara untuk dijalankan oleh pemerintahan Negara tersebut. Demokrasi merupakan hak rakyat untuk memilih pemimpin yang di inginkan oleh rakyat itu sendiri, seperti yang tertera di dalam Undang-undang Dasar Negara Repeublik Indonesia Pasal 1 ayat 2 yang berbunyi "Kedaulatan adalah di tangan rakyat, dan dilakukan sepenuhnya oleh Majelis Permusyawaratan Rakyat”. Di tinjau dari pasal 1 ayat 2, bisa disimpulkan bahwa Demokrasi merupakan kebebasan bagi rakyat Indonesia untuk memilih dan menentukan Pemimpin yang mereka inginkan tampa ada paksaan dari pihak manapun. Dalam melakukan pemilihan untuk menentukan seorang pemimpin tidaklah muda, maka dari itu di Indonesia sudah mengatur tentang bagaimana memilih seorang pemimpin yaitu dengan cara pemelihan umum (PEMILU).

Pemilu adalah sarana pelaksanaan kedaulatan rakyat yang dilkasanalan secara langsung, Mandiri, jujur, adil, kepastian hukum, tertib penyelenggara Pemilu, kepentingan umum, keterbukaan, proporsionalitas, profesionalitas, akuntabilitas, efisiensi, dan efektivitas berdasarkan pasal 2 Undang-Undang Repubilik Indonesia Nomor 22 Tahun 2007 tentang asas penyelanggaraan pemilu..

Komisi Pemilihan Umum, selanjutnya disingkat menjadi KPU, adalah lembaga penyelanggraan Pemilu yang bersifat Nasional, tetap, dan mandiri yang bertugas melaksnakan Pemilu. Komisi Pemilihan Umum Kabupaten/kota, selanjutnya disingkat KPUD, adalah penyelanggaraan pemilu yang bertugas melaksanakan pemilihan umum di tingkat kota/kabupaten. Komisi Pemilihan Umum Kabupaten/kota mempunyai tugas dan wewenang dalam menyelanggarakan pemilihan umum Presiden dan wakil Presiden di tingkat kabupaten/kota berdasarkan pasal 10 ayat 2 Undang-Undang Repubilik Indonesia Nomor 22 Tahun 2007. Pemilu merupakan instrument pelaksanaan kedaulatan rakyat dalam Negara. Pemilu sebagai penyaluran atas hak asasi manusia karena merupakan legalitas dan legitimasi politik dalam demokrasi modern. Dalam Negara yang mempunyai penduduk besar, demokrasi merupakan sistem perwakilan yang dipilih lewat pemilu dan peserta pemilu dapat secara kelembagaan (Parpol) atau perorangan. Indonesia merupakan Negara terbesar yang memilih pemimpin dengan cara pemilihan umum, seperti tertera di dalam Undang-undang Dasar Negara Republik Indonesia pasal $22 \mathrm{E}$ ayat 3 yang berbunyi " Pemilihan umum diselenggarakan untuk memilih anggota Dewan Perwakilan Rakyat, Dewan Perwakilan Daerah, Presiden dan Wakil Presiden dan Dewan Perwakilan Rakyat Daerah”. Dan Undang-Undang Nomor 23 Tahun 2003 tentang Pemilihan Umum Presiden dan Wakil Presiden (Lembaran Negara Republik Indonesia Tahun 2003 Nomor 93, Tambahan Lembaran Negara Republik Indonesia Nomor 4311). Pemilihan umum dilaksanakan lima tahun sekali dan pemilihan Presiden dan wakil Presiden baru saja dilaksanakan di

Muhammad Hidayansyah, dkk. Peran KPU dalam Meningkatkan Partisipasi Politik Masyarakat dalam Pemilihan Umum Presiden dan Wakil Presiden 2014 di Kota Malang 
Indonesia yaitu pada tanggal 09 Juli 2014 yang dimenangkan pasangan calon Presiden Joko Widodo dan wakil Presiden Yusuf Kalla sebagai presiden periode 2014-2019. Pemilihan umum ini dilakukan serentak di seluruh wilayah Indonesia termasuk di Kota Malang Propinsi Jawa Timur. Khusus Kota Malang suara tertinggi diraih oleh calon presiden nomor urut 2 yaitu presiden Joko Widodo dan wakil Presiden Yusuf Kalla dan sekarang sudah menjadi presiden dan wakil presiden untuk periode tahun 2014-2019. Kemenangan yang di raih oleh Joko Widodo dan wakil Presiden Yusuf Kalla tidak lepas dari kerja keras tim dan partai, dan khusus daerah Kota Malang suara terbanyak diraih oleh calon presiden dan wakil presiden Joko Widodo dan wakil Presiden Yusuf Kalla.

Pelaksanaan pemilihan umum (PEMILU) di Indonesia tidak lepas dari kerjasama tim yang di pusat dan di setiap daerah termasuk di daerah Kota Malang dengan berhasilnya PEMILU tahun 2014, KPU Kota Malang mempunyai peran penting sehingga pemilihan umum (PEMILU) tahun 2014 bisa berjalan dengan baik, dan dilihat dari pemilihan Presiden dan wakil presiden dari tahun 2004 dan 2009 partisipasi masyarakat Kota Malang sangatlah rendah, sedangka pada saat pemilihan presiden tahun 2014 partisipasi masyarakat Kota Malang sangat tinggi. Berdasarkan penjelasan yang sudah di paparkan di atas maka presentase respon masyarakat Kota Malang terhadap pemilihan umum presiden dan wakil presiden di tahun 2014 adalah $70 \%$, dengan presentase tersebut maka masyarakat Kota Malang sudah mengerti dan mengetahui bagaimana menjadi warga Negara yang baik yaitu salah satunya adalah dengan cara memilih presiden dan wakil presiden.
Penyelanggaraan pemilihan Prrsiden dan wakil Prseiden menurut Undang Undang Republik Indonesia nomor 42 tahun 2008 tentang pemilihan umum Presiden dan Wakil presiden mempunyai tahapan tahapan penyelanggaraan Pemilu Presiden dan Wakil Presiden meliputi : Penyusunan daftar Pemilih, Pendaftaran bakal Pasangan Calon, Penetapan Pasangan Calon, Masa Kampanye, Masa tenang, Pemungutan dan penghitungan suara, Penetapan hasil Pemilu Presiden dan Wakil Presiden dan Pengucapan sumpah/janji Presiden dan Wakil Presiden.

Pemilihan umum (PEMILU) selalu menjadi kegiatan yang selalu diminati oleh masyarakat Indonesia, salah satunya adalah pemilihan presiden dan wakil presiden, berdasarkan penjelasan diatas bahwa di Kota Malang pada pemilihan presiden dan wakil presiden tahun 2014 tingkat partisipasih masyarakatnya sangat meningkat dibandingkan tahun 2004 dan 2009, hal ini yang membuat peneliti tertarik untuk melakukan penelitian di Kota Malang, karena melihat pertisipasi masyarakat yang sangat tinggi, maka peneliti ingin mengetahui apakah meningkatnya partisipasi politik masyarakat di Kota Malang meningkatnya karena peran dari KPU Kota Malang atau meningkatnya partisipasi masyarakat Kota Malang karena ada faktor faktor lain seperti peran partai politik, dll.

\section{METODE}

Rancangan penelitian yang digunakan adalah rancangan penelitian deskriptif yang bertujuan membuat paparan secara sitematis, factual dan akurat mengenai fakta-fakta dan siafat-sifat populasi daerah tertentu secara harfiah, penelitian deskriptif 
merupakan penelitian yang bermaksud untuk membuat deskripsi mengenai situasisituasi atau kejadian-kejadian (Suryabrata, 2000:18-19).

Jenis pendekatan yang digunakan adalah pendekatan penelitian kualitatif, maksudnya adalah prosedur penelitian yang menghasilkan data deskriptif berapa katakata tertulis , lisan dan orang-orang dan perilaku yang dapat diamati . Jadi melalui pendekatan kualitatif akan didapatkan data deskriptif artinya tidak terbatas pada pengumpulan data dan penyusunan data melalui analisa dan interprestasi tentang data tersebut, data-data yang diperoleh secara tertulis dan lisan.

Data adalah bahan keterangan tentang suatu objek penelitian. Defenisi kata sebenarnya memiliki kemiripan dan definisi informasi, hanya informasi lebih ditonjolkan aspek materi (Bungin , 2001:123). Sumber data merupakan salah satu yang penting dalam penelitian. kesalahan dalam menggunakan atau memahami sumber data, maka data yang didapatkan tidak sesuai dengan yang diharapkan, untuk itu harus memahami sumber data yang diperoleh dari para informan (Bungin, 2001:129). Data primer diperoleh dengan cara melakukan wawancara dengan kompeten dengan menggunakan teknik purposive sampling. Teknik purposive sampling adalah teknik bertujuan memilih secara acak siapa yang dijadikan informan karena informan yang dipilih harus mengerti dan memahami masalah pemilihan Presiden dan Wakil Presiden 2014.

\section{HASIL DAN PEMBAHASAN}

Partisipasi Politik Masyarakat dalam Pemilihan Umum Presiden dan Wakil Presiden 2014 di Kota Malang.

Pemilihan umum merupakan kegiatan terbesar yang 5 tahun sekali dilaksanakan di Indonesia, kegiatan Nasional ini melibatkan seluruh Elemen masyarakat, dan melibatkan Komisi Pemilihan Umum Kabupaten/kota. Komisi Pemilihan Umum Kabupaten/kota mempunyai tugas dan wewenang dalam menyelanggarakan pemilihan umum Presiden dan wakil Presiden di tingkat kabupaten/kota. Pemilihan umum Presiden dan wakil presiden adalah suatau pesta rakyat yang terbesar di Indonesia, karena melibatkan semua masyarakat Indonesia dari Sabang sampai Merauke, pemilihan umum yang dilaksanakan pada tanggal 9 Juli 2014 kemarin memenangkan calon pasangan Presiden Joko Widodo dan wakil Presiden Yusuf Kalla sebagai prsiden dan wakil presiden Indonesia periode 2014-2019.

Melihat dari hasil Pemilihan Umum 9 Juli 2014, terkait dengan partisipasi masyarakat Kota Malang dalam Pemilihan Umum dapat dikatakan sangat baik, dikarenakan partisipasi masyarakat Kota Malang tahun 2014 meningkat di bandingkan tahun 2009, ini dikarenakan kerjasama seluruh pihak, dari KPU, Partai Politik, Pemerintahan Kota Malang, TNI, Polisi, dan Masyarakat Kota Malang. Meningkatnya partisipasi masyarakat Kota Malang sangat berpengaruh besar terhadap hasil suara yang menentukan Prseiden dan Wakil Presiden 2014-2009.

Partisipasi masyarakat mempunyai peningkatan yang sangat signifikan dan tolak ukur partisipasi politik masyarakat dilihat dari jumlah pemilih yang ikut dalam pemilihan umum kemarin, dengan melihat partisipasi masyarakat dalam pemilihan presiden dan wakil presiden maka masyarakat sangat antusias dalam mengikuti pemilihan umum, ini di karenakan masyarakat merupakan suatu system yamg mempunyai hubungan-hubungan yang ditata dan masyarakat merasa

Muhammad Hidayansyah, dkk. Peran KPU dalam Meningkatkan Partisipasi Politik Masyarakat dalam Pemilihan Umum Presiden dan Wakil Presiden 2014 di Kota Malang 
mempunyai identitas atau hak yang sama dalam mengikuti pemilihan umum, hal ini seperti yang dijelaskan oleh Robert M. Mclver dalam Budiardjo (2009:46) masyarakat adalah suatu sistem hubungan-hubungan yang ditata. Sementara itu, Koentjaraningrat mengatakan "Masyarakat adalah kesatuan hidup manusia yang berinteraksi menurut suatu sistem adat istiadat tertentu yang terikat oleh suatu rasa identitas bersama. Hal ini juga seperti yang dijelaskan oleh Ketua Devisi Sosialisasi, Organisasi dan Hubungan antar Lembaga KPU Kota Malang.

Mengacu pada hasil wawancara di atas dapat dijelaskan bahwa untuk melihat partisipasi politik masyarakat Kota Malang yang menjadi tolak ukur adalah jumlah pemilih yang ikut dalam pemilihan umum 2014 kemarin, maka dari itu bisa kita simpulkan bahwa pasrtisipasi masyarakat sangat besar dalam menentukan presiden dan wakil presiden 2014-2019, dan dari hasil Obeservasi tercatat masyarakat Kota Malang yang ikut berpartisipasi pada pemilihan umum presiden dan wakil presiden adalah sebanyak 459.506, dan dari data tersebut sebanyak 453.099 masyarakat Kota Malang yang mempunyai suarah sah, dan 6.407 suara tidak sah. Dalam pemilihan umum, masyarakat menjadi objek utama karena masyarakatlah yang mempunyai hak memilih dan tidak ada paksaan dari pihak lain.

Masyarakat Kota Malang sebagian besar sudah mengerti dan faham mengenai pemilihan umum, hal ini terlihat dari hasil observasi dan dari hasil wawancara kepada informan yang sebagian besar adalah masyarakat Kota Malang, meningkatnya keterlibatan masyarakat dalam penyelenggaraan Pemilihan Umum, menunjukan semakin kuatnya tatanan demokrasi dalam sebuah negara.
Demokrasi menghendaki adanya keterlibatan rakyat dalam setiap penyelenggaraan yang dilakukan negara. Rakyat diposisikan sebagai aktor penting dalam tatanan demokrasi, karena pada hakekatnya demokrasi mendasarkan pada logika persamaan dan gagasan bahwa pemerintah memerlukan persetujuan dari yang diperintah. Keterlibatan masyarakat menjadi unsur dasar dalam demokrasi, untuk itu, penyelenggaraan pemilu sebagai sarana dalam melaksanakan demokrasi, tentu saja tidak boleh dilepaskan dari adanya keterlibatan masyarakat.

Perilaku memilih merupakan realitas sosial politik, dari berbagai ragam masyarakat di Kota Malang, sebagai masyarakat yang bijak kita harus turut serta dalam proses pemilihan umum dalam rangka menentukan pemimpin yang akan memimpin kita, dengan demikian, secara tidak langsung kita akan menentukan pembuat kebijakan yang akan berusaha mensejahterakan masyarakat secara umum, dalam turut berpartisipasi dalam proses pemilihan umum sebagai masyarakat yang cerdas kita harus mampu menilai calon yang terbaik yang sekiranya mampu dan mau mendengarkan aspirasi masyarakat agar pembangunan yang akan dilakukan sesuai dengan keinginan masyarakat dan tidak memilih calon yang hanya mementingkan diri sendiri atau kelompoknya saja sehingga melupakan janji-janji yang sudah diucapkan dalam masa kampanye.

Masyarakat ikut memilih calon presiden dan wakil presiden karena mereka ingin mempunyai calon presiden dan wakil presiden yang bisa menepati janji-janjinya dan bisa mensejahterakan masyarakat. Figur calon presiden dan wakil presiden bisa mempengaruhi masyarakat, karena masyarakat bisa melihat dan menilai dengan 
sendirinya calon yang mereka inginkan, selain itu juga visi dan misi para calon juga bisa menjadikan salah satu alasan bagi masyarakat untuk ikut memilih sehingga tingkat partisipasih masyarakat Kota Malang semakin meningkat dalam pemilihan umum visi dan misi menjadi tolak ukur untuk menjadi calon pemimpin, selain itu juga masyarakat juga pasti mengetahui bagaimana prilaku calon pemimpin, dengan demikian maka masyarakat Kota Malang sebelum memilih calon presiden dan wakil presiden masyarakat harus benar-benar jeli dalam melihat dan mengamati calon presiden dan wakil presiden yang diinginkan oleh mereka.

Masyarakat Kota Malang sebagian besar mempunyai respon yang baik akan kegiatan pemilihan umum yang dilaksanakan 5 tahun ini, karena dalam pemilihan masyarakat bebas memilih calon pemimpin yang mereka inginkan, hal ini seperti yang di sampaikan oleh Sekertaris DPC PDIP Kota Malang yang sekaligus anggota DPRD Kota Malang Periode 2014-2019.

Partisipasih politik masyarakat pada pemilihan presiden dan wakil presiden di perlukan adanya dukungan dari semua elemen masyarakat, selain masyarakat Partai Politik juga melakukan dukungan dan bekerja sama dengan KPU Kota Malang guna berjalannya pemilihan umum dengan baik dan aman di Kota Malang, hal ini seperti hasil wawancara di atas bahwa peran partai politik sangat membantu KPU dalam melakukan sosialisasi, meskipun sosialisasi yang dilakukan oleh partai politik untuk mempromosikan calon presidenya sendri, tetapi dengan cara itu masyarakat bisa mengetahui tentang pemilihan umum dan tata cara pencoblosan.

Pemilihan umum adalah tanggung jawab besar bagi KPU, maka dari itu KPU tidak bisa melaksanakan kegiatan ini dengan sendri karena KPU pasti membutuhkan banyak bantuan dari semua pihak terutama pihak partai politik. Melihat kerjasama yang baik antar KPU dan partai politik, ini yang membuat pemilihan umum presiden dan wakil presiden 2014 bisa berjalan dengan baik khususnya di Kota Malang, dari hasil observasi dan pengamatan pada pemilhan umum tidak ada konflik yang berkepanjangan antaran partai politik dan KPU, dan tidak ada konflik antar sesama partai politik di Kota Malang, selain itu agar pesta demokrasi ini bisa berjalan dengan baik dan lancar, respon masyarakat Kota Malang yang sangat baik, dari informasih yang di dapatkan dilapangan, pemilihan umum presiden dan wakil presiden tahun 2014 hampir tidak ada Money Politics, dari hasil wawancara dengan masyarakat, hampir semuanya mengatakan tidak menenrima edaran uang politik

Praktek dari Money Politics dalam pemilu sangat beragam. Diantara bentukbentuk kegiatan yang dianggap politik uang antara lain seperti distribusi sumbangan baik berupa barang atau uang kepada para kader partai, penggembira, golongan atau kelompok tertentu, pemberian sumbangan dari konglomerat atau pengusaha bagi kepentingan partai politik tertentu, dengan konsesi-konsesi yang ilegal, dan penyalahgunaan wewenang dan fasilitas negara untuk kepentingan dan atau mengundang simpati bagi partai poltik tertentu, misalnya penyalahgunaan dana JPS atau penyalahgunaan kredit murah KUT dan lain-lain.

Dari sisi waktunya, praktik Money Politik di negara ini dapat dikelompokkan menjadi beberapa tahapan-tahapan yakni pra pemungutan. Pada pra pemungutan suara mulai dari seleksi administrasi, masa

Muhammad Hidayansyah, dkk. Peran KPU dalam Meningkatkan Partisipasi Politik Masyarakat dalam Pemilihan Umum Presiden dan Wakil Presiden 2014 di Kota Malang 
kampanye, masa tenang dan menjelang pemungutan. Sasarannya adalah para pemilih, terutama mereka yang masih mudah untuk dipengaruhi karena masyarakat sangat gampang di hasut atau di pengaruhi oleh orang lain maupun oknum-oknum politik lainnya, maka dari masyarakat harus jeli dan harus bisa menolak money politics yang datang dalam bentuk apapun yang di berikan oleh para oknum-oknum yang tidak bertanggung jawab itu. Karena peran masyarakat sangat besar dalam pemilihan umum, karena objek dalam pemilihan umum adalah masyarakat, tetapi terkadang hak mereka dibeli atau dibayar dengan uang oleh para calon pemimipin, tetapi dari penjelasan informan yang diwawancara, masyarakat Kota Malang tidak ada yang menerima uang money politics.

Praktek Money Politics atau yang lazim di kenal dengan Politik Uang, kerap terjadi di negeri ini pada setiap yang namanya Pemilihan, baik itu di kalangan Partai Politik/Organisasi Masya/ kepemudaan, maupun pemilihan dalam lingkaran pemerintahan, mulai dari tingkat Kepala Lingkungan/Kepala Desa, sampai kepada Pemilihan Kepala Daerah dan Calon Anggota Legeslatif/ bahkan sampai kepada tahap pemilihan kepala Negara.

Walaupun praktek Politik Uang yang di jalankan/di lakukan oleh para calon yang akan dipilih, namun amatlah sukar untuk membuktikannya. Seperti apa yang di katakan Oleh Riyas Rasyit penggagas Otonomi Daerah yang mengatakan bahwa Money Politik itu ibarat kentut. Yang tercium hanya baunya, namun untuk membuktikan siapa yang kentut sangatlah sukar. Karena bagaimanapun sipenerima uang dari calon yang akan dipilih tidak akan berani untuk buka mulut, disebabkan ada nya Undang undang yang mengatur, si pemberi dan si penerima sama sama melakukan korupsi dan diancam dengan hukuman penjara, tetapi dari hasil observasi dan wawancara bahawa masyarakat Kota Malang hampir $70 \%$ tidak ada yang menerima suap atau menerima edaran money politik yang dilakukan beberapa oknum pada pemilihan umum presiden dan wakil presiden 2014 kemarin. Secara garis besar pemilihan presiden dan wakil presiden 2014 masyarakat Kota Malang memilih sesuai dengan keinginan dan kemauan hati, karena masyarakat Kota Malang bersih dari money politik.

\section{Peran KPU Kota Malang dalam Pemilihan Umum Presiden dan Wakil} Presiden 2014.

Sejak kemerdekaan hingga tahun 2014 bangsa Indonesia telah menyelenggarakan 11 kali pemilihan umum, yaitu 1945, 1971, 1977, 1982, 1992, 1997, 1999, 2004, 2009 dan 2014. Akan tetapi pemilihan pada tahun 1955 merupakan pemilihan umum yang dianggap istimewa karena ditengah suasana kemerdekaan yang masih tidak stabil Indonesia melakukan PEMILU, bahkan dunia internasional memuji pemilu pada tahun tersebut. Pemilihan umum berlangsung dengan terbuka, jujur dan fair, meski belum ada sarana komunikasi secanggih pada saat ini atau pun jaringan kerja KPU, tetapi saat ini KPU mempunyai peran yang sangat penting dan sangat besar dalam pelaksanaan pemilihan presiden dan wakil prsiden di Indonesia

Peran KPU sangat besar, karena dengan adanya KPU maka kegiatan pemilihan umum presiden dan wakil presiden bisa berjalan dengan baik, bisa bergerak cepat bahkan bisa menyatukan masyarakat Indonesia dari Sabang sampai Merauke, semuanya dilakukan untuk memudahkan masyarakat dalam 
menentukan presiden dan wakil presiden Indonesia. Pemilihan Umum presiden dan wakil presiden adalah sarana pelaksanaan kedaulatan rakyat yang diselenggarakan secara langsung, umum, bebas, rahasia, jujur dan adil dalam Negara Kesatuan Republik Indonesia berdasarkan Pancasila dan Undang-Undang Dasar Negara Republik Indonesia Tahun 1945. Agar terwujudnya tujuan utama pemilu yang langsung, umum, bebas, rahasia, jujur dan adil kepada para pemilih. Maka peran KPU menjadi salah satu tonggak utama dalam mengsukseskan pemilihan umum presiden dan wakil presiden 2014.

Peran KPU Kota Malang dalam pemilihan umum tahun 2014 sangat besar, sehingga tingkat partisipasih masyarakat di Kota Malang sangat meningkat, peran KPU bukan hanya sekedar penyelenggera tetapi sebagai media untuk menyampaikan informasih kepada masyarakat agar masyarakat bisa menjadi pemilih yang bak dalam pemilihan umum 2014. Selain itu peran KPU juga adalah menyediakan dan memfasilitasi masyarakat dalam melakukan kegiatan pemilihan umum, KPU mempunyai tanggung jawab yang besar dalam menyelenggarakan kegiatan ini, peran penting KPU lah yang bisa membawa system demokrasi di Indonesia semakin baik, karena dengan kinerja KPU yang baik dan jujur, maka masyarakatpun bisa leluasa memberikan hak mereka dalam pemilihan pemilihan presiden dan wakil presiden 2014. Dengan berbagai macam cara yang dilakukan oleh KPU Kota Malang, dari menyediakan layanan bagi masyarakat sampai dengan melakukan sosialisasi. Hal ini sesuai dengan hasil wawancara dan observasi yang di lapangan, dan sebagaimana dokumen berikut ini, yang menjelaskan bagaimana peran KPU Kota Malang.
Pemilihan umum merpukan kerja keras KPU dalam melaksanakan pemilihan presiden dan wakil presiden, tetapi kerja keras KPU Kota Malang harus di topan dengan partisipasi masyarakat Kota Malang, dari beberapa informan yang di wawancarai, memang masyarakat Kota Malang mengetahui tentang politik, tentang tata cara pencoblosan itu melalui sosialisasi dari KPU Kota Malang, sehingga masyarakat mengerti dan memahami tentang pencoblosan. Seperti yang di utarakan oleh salah satu informan yang telah diwawancarai, mereka mengaku mendapat info dari KPU ketika KPU melakukan sosialisasi, karena dari pihak KPU melakukan sosialisasi bukan hanya bertatap muka tetapi KPU bersosialisasi melalui beberapa media seperti TV, Koran, Radio.

Strategi yang dilakukan oleh KPU adalah strategi yang sangat bagus, karena KPU melakukan sosialisasi bukan hanya dengan satu cara, tetapi KPU melakukan sosialisasi dengan berbgai cara dari bersosialisasi bertatap muka sampai dengan Panflet, baliho, dll. Segala cara yang dilakukan oleh KPU Kota Malang untuk memberikan informasih kepada masyarakat Kota Malang hal ini lah yang membuat peran KPU Kota Malang semakin baik karena dengan adanya peran KPU masyarakat Kota Malang semakin tau dan semakin mengerti akan hak dan kawajiban mereka sebagai rakyat Indonesia, dengan sosialisasi yang dilakukan oleh KPU maka masyarakat Kota Malang semakin mengerti akan tentang pemilihan umum. Dari berbagai sosialisasi yang dilakukan oleh KPU salah satu yang sangat menunjang agar peran masyarakat meningkat, KPU melakukan beberapa hal seperti dengan dokumen berikut ini, yang dimana KPU melakukan sosialisasi kepada masyarakat.

Muhammad Hidayansyah, dkk. Peran KPU dalam Meningkatkan Partisipasi Politik Masyarakat dalam Pemilihan Umum Presiden dan Wakil Presiden 2014 di Kota Malang 
Selain bersosialisasi, peran KPU adalah memberikan ruang kepada partai politik untuk melakukan sosialisasi, karena KPU juga bekerja sama dengan semua pihak untuk melaksanakan dan melancarkan pemilihan presiden dan wakil presiden 2014, dengan kerjasama dengan semua pihak maka pemiihan umum bisa berjalan dengan baik, pekerjaan KPU bukan hanya mengsuskseskan pemilihan umum 2014, tetapi juga harus meningkatkan partisipasi masyarakat, tetapi harus di akui oleh KPU bahwasanya peran partai politik juga sangan besar dalam hal pemilihan umum.

Peran KPU Kota Malang sangat besar, selain dari berbagai sosialisasi yang dilakukan KPU juga menjalin kerja sama dengan beberpa pihak dari pemerintahan sampai dengan partai politik, selain pemerintah dan partai politik, KPU juga bekerjasama dengan pihak keamanan seperti Kepolisian dan TNI, kerjasama ini sangat berguna karena pemilihan umum rentang akan kehilangan suara, kerusukan, TPS, demo atau barbagai macam masalah lainya. Dari hasil observasi dan dokumen yang didapatkan keberadaan pihak keamanan sangat diperlukan sekali,

Mengacu dari penjelasan para informan di atas, mengatakan bahwa sangat besar peran KPU Kota Malang dalam meningkatkan partisipasi masyarakat dalam pemilihan umum presiden dan wakil presiden 2014, terlihat dari bebagai cara yang dilakukan oleh KPU, dari melakukan sosialisasi, sampai bekerja sama dengan Pemerintahan, partai politik dan pasti masyarakat pun ikut berpartisipasi dalam mendukung kinerja KPU terlihat banyaknya relawan relawan yang iku membatu KPU dalam kegiatan pemilihan umum, sehingga KPU tidak bekerja sendiri, berhasilyan pemilihan umum 2014 kemarin karena kerjaama KPU Kota Malang dengan semua pihak.

Faktor Pendukung dan Penghambat KPU Kota Malang dalam meningkatkan Partisipasi masyarakat dalam Pemilihan Presiden dan Wakil Presiden 2014.

Banyak faktor yang membuat partisipasi masyarakat dalam sebuah pemilihan bisa meningkat dan terkadang juga bisa menurun, tampa terkecuali pemilihan presiden dan wakil presiden. Faktor masyarakat tidak ikut dalam pemilihan bisa jadi kurangnya informasih yang mereka terima, sehingga mereka tidak menggunakan hak pilihnya karena memilih Golput atau Apatis terhadap pemilihan karena semakin berkurangnya tingkat kepercayaan mereka terhadap pemimpinnya. Dalam suatu masyarakat terkadang usaha meningkatkan tingkat pemilih bisa dilakukan dengan berbagai cara dan tidak jauh dengan faktor penghambat dan faktor pendukunganya.

Pemilihan umum bukanlah kegiatan yang sederhana, tetapi pemilihan umum adalah suatu kegiatan yang sangat besar, kegiatan yang mencakup seluruh elemen masyarakat yang ada di Indonesia, pemilihan umum presiden dan wakil presiden merupakan kegiatan yang membutuhkan kerjasama yang baik, tetapi tekadang pada saat kegiatan berlangsung pasti akan ada beberapa faktor yang menghambat dan faktor yang mendukung

Faktor pendukung dan faktor penghambat dalam suatu kegiatan pasti ada, apalagi kegiatan Pemilu yang melibatkan hampir seluruh masyarakat Indonesia, selain itu faktor pendukung dan faktor penghambat adalah bukti nyata bahwa menjalankan kegiatan besar seperti pemilihan umum bukanlah perkara yang gampang, pasti akan ada beberapa permasalahan yang ditemui dalam 
melakukan kegiatan dari persoalan pemilih tetap, hak suara, money politics, demo, maka dari itu dari permasalahan yang di dapatkan maka di perlukan kerjasama dengan bebrapa pihak, salah satunya adalah pihak keamanan, dari hasil wawancara dan observasi di atas maka bisa kita simpulkan bahwa faktor penghambat dan pendukung itu ada. Hal ini di dukung oleh gambar berikut ini.

Faktor pendukung dan faktor penghambat akan selalu ada di setiap kegatan pemilihan umum, seperti pada saat melakukan sosialisasi tentang pemilihan umum kepada masyarakat Kota Malang. Faktor pendukung dan faktor penghambat selalu menjadi bahan evaluasi yang selalu dilakukan dalam setiap kegiatan, karena Faktor pendukung dan faktor penghambat adalah bagian yang tidak bisa kita lupakan atau kita hapus, Faktor pendukung dan faktor penghambat menjadi bagian yang penting pada saat kegiatan yang akan kita lakukan selanjutnya. Dari hasil observasi, mengacu dari hasil penelitian dan hasil wawancara yang dilakukan di berbagai informan, faktor pendukung dan faktor penghambat selalu menjadi titik perhatian, karena itu bisa menjadi bahan evalauasi kembali dan faktor pendukung dan faktor penghambat akan selalu ada di setiap kegiatan yang kita lakukan.

\section{SIMPULAN}

Partisipasi politik masyarakat dalam pemilihan presiden dan wakil presiden 2014 di Kota Malang sangat baik, bahkan sangat meningkat di bandingkan partisipasi pada tahun tahun sebelumnya. Hal ini dilihat dari meningkatnya partisipasi mencapai 70\%, sedangkang tingkat Golput semakin menurun yaitu 30\%, hal ini menandakan bahwa masyarakat Kota Malang sudah mengerti dan memahami tentang politik dan sudah mengerti bagaimana mencoblos, dan sudah memberikan hak pilihnya pada saat pemilihan presiden dan wakil presiden 2014.

Peran KPU Kota Malang dalam pemilihan umum presiden dan wakil presiden 2014 sangat besar, karena KPU merancang kegiatan dengan baik, dari sosialisasi, pengurusan data, sampai hari $\mathrm{H}$ pencoblosan, semua dilakukan oleh KPU guna meningkatkan partisipasi masyarakat Kota Malang dalam pemilihan umum 2014, peran KPU Kota Malang mempunyai dampak positif terhadap partisipasi masyarakat Kota Malang sehingga terjadi peningkatan yang sangat signifikan dari paertisipasi masyarakat Kota Malang pada pemilihan umum presiden dan wakil presiden 2014.

Faktor pendukung dan faktor penghambat KPU Kota Malang dalam meningkatkan partisipasi masyarakat dalam pemilihan presiden dan wakil presiden di Kota Malang sangat beragam dari faktor pendukung, seperti banyaknya masyarakat yang ingin menjadi relawan dalam pemilihan umum presiden dan wakil preiden 2014, selain itu adannya kerja sama KPU Kota Malang dengan Pemerintahan Kota Malang, Partai Politik, TNI, Polri, dan juga kerja sama dengan masyarakat, sedangkan faktor penghambatnya terdiri dari beberapa faktor seperti faktor teknis, faktor dana yang di alokasikan kepada KPU untuk menjalankan kegiatan pemilihan umum presiden dan wakil presiden, selain itu juga faktor data masyarakat yang berpindah penduduk, dan faktor sosialisasi yang sedikit kurang berjalan baik di karenakan masalah dana dan masalah lainnya.

Berdasarkan hasil penelitian dan observasi di lapangan, dengan kesimpulan

Muhammad Hidayansyah, dkk. Peran KPU dalam Meningkatkan Partisipasi Politik Masyarakat dalam Pemilihan Umum Presiden dan Wakil Presiden 2014 di Kota Malang 
yang sudah tertera di atas, melalui banyak pertimbangan dari hasil penelitian yang di lakukan dan ada beberapa saran yang ingin di sampaikan yaitu: Diharapkan kepada masyarakat Kota Malang untuk meningkatkan lagi pengetahuan tentang politik, tentang menjadi masyarakat yang baik dan benar tampa harus golput apalagi menerima uang dari pihak mana pun demi membeli hak suara anda, pemilu harus melatih seluruh masyarakat di Indonesia untuk tetap jujur, untuk tetap semangat mengikuti pemilihan umum yang dimana dilakukan lima tahun sekali yang diperuntukan untuk masyarakat, maka ikutilah agar masyarakat bisa menentukan pemimipin untuk indoneia kedepannya.

Bagi KPU Kota Malang semoga kedepannya lebih bagus lagi dalam melakukan tugas dan kewajiban guna meningkatkan partisipasi masyarakat Kota Malang, dan lakukanlah sosialisasi bukan hanya di daerah Kota saja, tetapi juga di daerah daerah pinggir Kota, dan juga jangan sampai ada masyarakat Kota Malang yang tidak mengikuti pemilihan presiden maupun pemilihan pemilihan yang lainnya. Semoga untuk kedepanya masyarakat dan KPU Kota Malang bisa bekerja sama dengan baik, dan juga kerja sama dengan pihak pihak yang lain seperti Pemerintahan, Partai Politik, Polri dan TNI,dan semoga di pemilihan umum yang akan datang partisipasi masyarakat semakin meningkat, dan kinerja KPU semakin baik lagi.

\section{DAFTAR PUSTAKA}

Budiardjo. Miriam. 1998. Partisipasi dan Partai Politik. Jakarta: Yayasan Obor Indonesia.

Bungin. Burhan. 2001. Metode Penelitian Sosial. Surabaya: Airlangga university Press.
Undang-undang Dasar Negara Repeublik Indonesia Pasal 1 ayat 2.

Undang-undang Dasar Negara Republik Indonesia pasal $22 \mathrm{E}$ ayat 3.

Undang-Undang Nomor 23 Tahun 2003 tentang Pemilihan Umum Presiden dan Wakil Presiden (Lembaran Negara Republik Indonesia Tahun 2003 Nomor 93, Tambahan Lembaran Negara Republik Indonesia Nomor 4311).

Undang-Undang Republik Indonesia Nomor 42 Tahun 2008 Tentang Pemilihan Umum Presiden Dan Wakil Presiden.

Undang-Undang Repubilik Indonesia pasal 10 ayat 2 Nomor 22 Tahun 2007. 